\title{
Perlindungan Hukum Investor di Pasar Modal melalui Fungsi Penjaminan Penyelesaian Transaksi Bursa.
}

\author{
Lastuti Abubakar\& Tri Handayani \\ Fakultas Hukum Universitas Padjadjaran \\ lastuti62abubakar@gmail.com
}

\begin{abstract}
Legal protection to the Investor is an important role to attract investment in the capital market. We need a mechanism to guarantee the transactions in order to avoid failure to deliver or to pay. To optimize the Guarantee Fund, it is necessary to consider the use of the concept of trust as a legal based. Furthermore, KPEI guarantees settlement of exchange transactions using existing financial resources by still imposing obligations on Clearing Members to replace (subrogation). To optimize the assurance fund managed by KPEI, it is worth considering the use of trust concept as legal basis. In form of Trust concept, KPEI will act as a Trustee (Legal owner) who can manage and invest the funds optimally, while the beneficiaries (beneficial owner) is the interest of the capital market industry. The use of trust concept that adheres to dual ownership needs to be adapted to the Indonesian legal system that is not familiar with dual ownership. Therefore, it is necessary to refer to the use of the concept of trust in POJK No. 25/POJK.03/2016 concerning the amendment of POJK No. 27/POJK.03/2015 concerning Bank business activities of the Bank in the form of trust as the development of banking services.
\end{abstract}

\section{Keywords: Capital Market Investor, Legal Protection, Transaction Settlement Guarantee.}

\begin{abstract}
Abstrak
Perlindungan hukum investor berperan penting untuk menarik investasi di pasar modal karena investasi akan mengalir ke tempat yang mendatangkan keuntungan optimal dan mampu menjamin bahwa investasi dan keuntungan akan diperoleh. Oleh karena itu, diperlukan mekanisme transaksi yang dapat menjamin transaksi agar tidak terjadi gagal serah atau gagal bayar. Sebagai Lembaga Kliring dan Penjaminan, KPEI berfungsi sebagai mitra pengimbang yang menggantikan kedudukan para pihak melalui novasi subyektif. Selanjutnya, KPEI menjamin penyelesaian transaksi bursa dengan menggunakan sumber-sumber keuangan yang ada dengan tetap membebankan kewajiban pada Anggota Kliring untuk mengganti (subrogasi). Untuk mengoptimalkan Dana Jaminan yang dikelola oleh KPEI, perlu dipertimbangkan penggunaan konsep trust sebagai dasar hukum. Melalui trust, KPEI akan bertindak sebagai trustee (legal owner) yang dapat mengelola dan menginvestasikan dana secara optimal, sedangkan penerima manfaatnya (beneficial owner) adalah kepentingan industri pasar modal. Penggunaan konsep trust yang menganut dual ownership ini perlu diadaptasi dan disesuaikan dengan sistem hukum Indonesia yang tidak mengenal dual
\end{abstract}


ownership. Oleh keran itu, perlu dirujuk penggunaan konsep trust dalam POJK No. 25/POJK.03/2016 Tentang Perubahan Atas POJK No. 27/POJK.03/2015 Tentang Kegiatan Usaha Bank Berupa penitipan dengan Pengelolaan (Trust) sebagai pengembangan jasa perbankan.

\section{Kata Kunci: Investor Pasar Modal, Perlindungan Hukum, Penjaminan Penyelesaian Transaksi.}

\section{Pendahuluan}

Pasar Modal mempunyai fungsi penting dalam pembangunan ekonomi nasional. Selain sebagai alternatif pembiayaan dunia usaha, pasar modal juga merupakan alternatif investasi bagi pemodal, baik bagi pemodal domestik maupun asing, dan pemodal institusional maupun perorangan. Saat ini, sumber pembiayaan masih di dominasi oleh perbankan, namun perkembangan pasar modal dari waktu ke waktu menunjukkan perkembangan yang signifikan. Namun demikian, berdasarkan data OJK pada tahun 2018 terjadi penurunan Indeks Harga Saham Gabungan (IHSG) sebesar 2,54\% dan nilai emisi sebesar 34,75\%, jumlah Emiten baru bertambah 20 Emiten (31,58\%) dan jumlah Penawaran Umum mengalami kenaikan sebesar 4,35\%. Hal ini menunjukkan bahwa kondisi pasar modal Indonesia sebagai pasar yang sedang tumbuh (emerging market)tidak dapat dilepaskan dari pengaruh kondisi ekonomi global ( OJK, 2018 : 17). Selain itu, data tersebut menunjukkan bahwa kepercayaan korporasi untuk menarik dana masyarakat melalui pasar modal masih tinggi. Pemilihan pasar modal sebagai alternatif pembiayaan ini tentu tidak dapat dilepaskan dari keniscayaan bahwa potensi investasi dari pemilik modal (investor) di pasar modal masih besar. Kunci dari keberhasilan pasar modal untuk menarik investasi adalah adanya perlindungan dan kepastian berinvestasi. Hal ini menjadi urgen bagi pasar karena investor tidak memiliki akses langsung pada perusahaan emiten yang menerbitkan efek atau surat berharga yang diterbitkan. Berbeda dengan investasi langsung (direct investment), investor ikut serta menjadi bagian manajemen perusahaan bahkan bukan tidak 
mungkin menjadi pengendali perusahaan apabila kedudukannya sebagai pemegang saham mayoritas atau pengendali, terutama dalam penanaman modal asing (foreign direct investment). Secara fundamental, investor dalam penanaman modal asing berkeinginan untuk memiliki perusahaan di negara lain atau membangun usaha baru yang lebih luas dibandingkan melalui pihak ketiga seperti agen atau supplier ( Laura Alfaro \& Jasmina Chaufin, 2017 : 6). Hal ini berbeda dengan kedudukan investor pasar modal yang merupakan investasi dalam bentuk portofolio ( portfolio investment). Investor pasar tidak bertujuan untuk memiliki atau mengendalikan perusahaan, namun semata mata menginginkan keuntungan yang berasal dari selisih harga jual dan harga beli (capital gain).Bahkan keuntungan perusahaan yang dibagikan (dividen) bukanlah menjadi tujuan investor di pasar modal. Itu sebabnya, investasi di pasar modal bersifat spekulatif, yaitu tidak ada seorang pun yang dapat memastikan kapan capital gain dapat diperoleh mengingat turun naiknya harga saham di Bursa hanya dapat diprediksi, bukan dipastikan. Namun demikian, kedua jenis investasi tersebut saling melengkapi, bukan menggantikan (Marchin Humanicki.et.al, 2013 : 27). Investasi di pasar modal berlandaskan pada 2 (dua) prinsip umum dalam berinvestasi, yaitu 1) prinsip " high risk, high return”, yaitu semakin besar risiko yang dihadapi, semakin besar keuntungan yang akan diperoleh di masa yang akan datang (Abdul Qoyum.et.al, 2017 : 285) ; 2) Oleh karena itu, risiko investasi ini perlu dikelola secara optimal, termasuk jaminan kepastian dan perlindungan hukum atas investasi yang dikeluarkan. Selain itu, investasi di pasar modal bersifat spekulatif yang keuntungan investasinya tidak semata-mata bergantung pada fundamental ekonomi Perusahaan Publik (Emiten), namun juga dipengaruhi oleh faktor-faktor lain seperti kebijakan pemerintah, sosial, dan politik. Selain itu, Emiten wajib mengungkapkan informasi material yang harus diketahui oleh publik. 
Hal ini sejalan dengan prinsip transparansi sebagai prinsip utama di pasar modal yang akan mempengaruhi keputusan investor dalam berinvestasi (Mohamad Heykal, 2013 : 707).

Sebagai bagian dari pasar modal global, keikutsertaan Otoritas Pasar Modal Indonesia dalam berbagai lembaga internasional akan mempengaruhi regulasi dan kebijakan yang diberlakukan di pasar modal Indonesia. Penerapan standar internasional dalam praktik pasar modal Indonesia menjadi salah satu upaya untuk menarik investor global. Sistem perdagangan yang memberikan kepastian dan perlindungan hukum bagi investor menjadi urgen dalam pengembangan pasar modal. Salah satu standar internasional yang direkomendasikan oleh IOSCO adalah sistem perdagangan tanpa warkat (scripless trading system) yang sudah diterapkan sejak pertengahan tahun 2000. Sistem perdagangan tanpa warkat ini merupakan sistem perdagangan berbasis teknologi informasi yang meniadakan bukti fisik efek. Fisik seluruh efek yang diperdagangkan dibursa dikonversikan menjadi bentuk elektronik. Perubahan bentuk efek berupa data elektronik ini tentu memiliki implikasi yuridis terhadap beberapa aspek hukum seperti bukti kepemilikan saham dan mekanisme saham PT Terbuka sebagai objek jaminan (Lastuti Abubakar\& Tri Handayani,2018 : 186-206). Bursa Efek dikonversikan menjadi data elektronik. Perubahan Walaupun sistem perdagangan ini diterapkan pada pertengahan tahun 2000, Undang-Undang Nomor 8 Tahun 1995 Tentang Pasar Modal ( UU Pasar Modal) telah mengamanatkan tentang penggunaan sistem perdagangan tanpa warkat ini. Hal ini dapat disimpulkan dari pengaturan di dalam Pasal 55 Ayat (1) UU Pasar Modal, yaitu : "Penyelesaian Transaksi Bursa dapat dilaksanakan dengan penyelesaian pembukuan, penyelesaian fisik, atau cara lain yang ditetapkan dengan Peraturan. Selanjutnya, Penjelasan Pasal 55 Ayat (1) menjelaskan bahwa yang dimaksud dengan penyelesaian pembukuan (book entry settlement) adalah " pemenuhan hak 
dan kewajiban yang timbul sebagai akibat adanya Transaksi Bursa yang dilaksanakan dengan cara mengurangi Efek dari rekening Efek yang satu dan menambahkan Efek dimaksud pada rekening Efek yang lain pada Kustodian, yang dalam hal ini dapat dilakukan secara elektronik". Berdasarkan Pasal 55 Ayat (1) UU Pasar Modal ini, sistem perdagangan tanpa warkat ini memiliki dasar hukum yang tegas dan kuat. Tindak lanjut dari Pasal ini adalah bagaimana sistem ini dapat memberikan jaminan kepastian dan perlindungan hukum bagi setiap pihak yang bertransaksi di Pasar Modal Indonesia. Kepastian dan perlindungan hukumbagi inestor di pasar modal ini dibutuhkan untuk menjadikan pasar modal Indonesia dapat menjadi pilihan alternatif investasi yang menarik baik bagi investor global maupun investor lokal. Hal ini sejalan dengan karakteristik investasi yaitu aliran investasi akan menuju pada tempat yang menghasilkan keuntungan yang lebih besar. Oleh karena itu, faktor keuntungan perusahaan merupakan faktor yang paling berpengaruh terhadap pengambilan keputusan investasi (Natalia Christanti \& Linda Ariany, 2011 : 38). Hal ini sejalan dengan salah satu tujuan dari pengaturan pasar modal yang diterbitkan oleh IOSCO 2017, yaitu perlindungan investor. salah satu dari 38 prinsip yang erat kaitannya dengan perlindungan dan kepastian hukum bagi investor ini adalah Principle Relating to Clearing and Settlement (prinsip yang berkenaan dengan Kliring dan Penyelesaian). Berdasarkan prinsip ini sistem penyelesaian efek, sentral penyimpanan efek, repositori perdagangan dan mitra pengimbang (counterparty) harus tunduk pada regulasi dan pengawasan yang dirancang untuk memastikan bahwa perdagangan berjalan dengan adil, efektif dan efisien dan mengurangi risiko sistemik ( IOSCO, 2017 : 13). Mengacu pada prinsip tersebut maka ada dua kata kunci terkait dengan fungsi kelembagaan, yaitu fungsi kliring dan penjaminan, serta penyelesaian transaksi. Di dalam struktur organisasi Pasar Modal Indonesia, fungsi Kliring dan Penjaminan dilakukan oleh Lembaga 
Kliring dan Penjaminan (LKP) yang dilaksanakan oleh PT Kliring dan Penjaminan Efek Indonesia (PT KPEI), sedangkan penyelesaian transaksi dilakukan oleh Lembaga Penyimpanan dan Penyelesaian (LPP) yang dilaksanakan oleh PT Kustodian Sentral Efek Indonesia (PT KSEI). Kedua lembaga ini merupakan Self Regulatory Organization (SRO) yaitu organisasi yang diberi kewenangan untuk membuat dan menerapkan peraturan terkait fungsinya di pasar modal. Sesuai dengan amanat UU Pasar Modal bahwa tugas LKP adalah untuk menyediakan jasa kliring dan fungsi penjaminan penyelesaian transaksi bursa. Dimaksudkan dengan kegiatan kliring adalah proses penentuan hak dan kewajiban atas transaksi bursa dari setiap Anggota Kliring(AK) yang wajib diselesaikan pada tanggal penyelesaian. Adapun fungsi penjaminan penyelesaian transaksi bursa dilakukan dengan cara memberikan kepastian secara hukum untuk dipenuhinya hak dan kewajiban bagi AK yang timbul dari transaksi bursa. Secara terus menerus
KPEI melakukan peningkatan kualitas layanan jasa dan produk untuk memenuhi ekspektasi pelaku pasar. Sebagai pengembangan institusional, KPEI juga selalu berupaya dalam melakukan perbaikan infrastruktur, riset dan pengembangan serta penerapan praktik terbaik standar internasional sebagai Central Counterparty (KPEI, 2015). Dalam menjalankan fungsi sebagai LKP, KPEI mengacu pada Principles for Finansial Market Infrastructure yang diterbitkan oleh the Commitee on Payment and Settlement Systems (CPPS) dan Technical Commitee of the Internasional Organization of Securities Commissions (IOSCO). Pedoman ini ditujukan untuk memberikan standar yang komprehensif bagi suatu Financial Market Infrastructure (FMI) yang berperan dalam memfasilitasi kegiatan pembayaran, mendukung proses dan aktivitas penyelesaian transaksi maupun penyimpanan instrumen keuangan. Finansial Market Infrastructure ini merupakan aspek penting dalam sistem keuangan maupun perekonomian di 
seluruh dunia, karena jika tidak dikelola dengan baik, FMI justru dapat menjadi sumber krisis keuangan (KPEI, 2015).

Demikian juga halnya dengan PT KSEI yang diberi kewenangan untuk mengatur dan menerapkan peraturan terkait fungsinya sebagai lembaga yang menyediakan layanan jasa Kustodian sentral dan penyelesaian transaksi Efek yang teratur, wajar, dan efisien sesuai amanat UU Pasar Modal. Bersama dengan Bursa Efek Indonesia (BEI) dan KPEI, KSEI menerapkan transaksi perdagangan dan penyelesaian Efek tanpa warkat (scripless trading) di Pasar Modal Indonesia. Penerapan sistem tersebut didukung oleh sistem utama KSEI yaitu The Central Depository and Book-Entry Settelement System (CBEST) ( KSEI, 2016 ).

Namun demikian, dalam menjalankan fungsinya, KPEI dihadapkan pada risiko kredit yang berpotensi akan muncul. Hal ini sebagai akibat ketidakmampuan AK tertentu untuk memenuhi kewajiban ke KPEI atau gagal bayar. Beberapa kasus gagal bayar yang mengemuka antara lain pada Agustus 2002, PT Usaha Bersama Sekuritas mengalami gagal bayar atas transaksi saham. KPEI memperkirakan adanya potensi kegagalan beruntun sebesar Rp. 30.986.550.000. selanjutnya, KPEI memutuskan untuk menunda penyelesaian transaksi tersebut. Keputusan ini telah sesuai dengan surat Ketua Bapepam-LK tanggal 11 November 2002 untuk memberikan kesempatan kepada Bapepam-LK (sekarang OJK) untuk melakukan penyidikan atas adanya indikasi transaksi yang tidak wajar. Sampai dengan penerbitan laporan keuangan (2017) KPEI masih melakukan penundaan penyelesaian sehubungan dengan status hukum transaksi tersebut. Selain itu, berdasarkan Surat Keputusan No. SR-02/BL/2009 tertanggal 6 Januari 2009, BapepamLK telah memerintahkan KPEI untuk melakukan pembekuan aset-aset atas nama PT Sarijaya Permana Sekuritas (SPS) sehubungan dengan proses pemeriksaan yang sedang dilakukan Bapepam-LK terhadap adanya dugaan pelanggaran peraturan perundang-undangan di bidang pasar modal yang diduga dilakukan oleh 
SPS, kecuali aset-aset untuk penyelesaian transaksi bursa yang terjadi sebelum keluarnya surat tersebut. Kasus ini diselesaikan melalui pengadilan sampai tingkat kasasi, dengan tuntutan oleh beberapa nasabah kepada SPS selaku perusahaan sekuritas, menteri keuangan, Bapepam-LK, KPEI dan KSEI. Berdasarkan putusan dari pengadilan negeri sampai Mahkamah Agung , maka terbukti SPS melakukan wanprestasi dan wajib membayar ganti rugi kepada para nasabah. Dari ke dua kasus diatas, dapat dilihat bahwa kegagalankegagalan dalam pemenuhan kewajiban Anggota Kliring akan selalu bersinggungan dengan KPEI selaku penjaminan transaksi. Namun demikian, tidak berarti setiap kegagalan dalam pemenuhan kewajiban AK akan dijamin oleh KPEI (KPEI,2017 : 267).

Adapun risiko-risiko yang berpotensi muncul adalah risiko kredit, yang dapat muncul dari Anggota Kliring dan Bank Pembayar dan atau Bank Penerbit Kas \& Setara Kas, yaitu pihak yang berhubungan dengan KPEI yang menimbulkan risiko kredit kepada KPEI akibat dari aktivitas penyelesaian transaksi bursa, pengelolaan agunan dan dana jaminan serta pengelolaan sumber keuangan KPEI. Selain risiko kredit, KPEI wajib mengelola risiko likuiditas secara efektif, dan risiko pasar.

Selanjutnya, mengacu pada Peraturan OJK No. 26/POJK.04/2014 Tentang Penjaminan Penyelesaian Transaksi Bursa, KPEI berkewajiban secara seketika dan langsung mengambil alih tanggung jawab AK yang mengalami kegagalan dalam memenuhi kewajibannya berkaitan dengan penyelesaian transaksi bursa dan untuk menyelesaikan transaksi tersebut pada waktu dan cara yang sama sebagaimana diwajibkan kepada anggota AK yang bersangkutan. Isu hukum yang harus diantisipasi adalah kedudukan KPEI sebagai Finansial Market Infrastructure yang berpotensi menimbulkan risiko sistemik. Potensi ini sejalan dengan perkembangan fungsi KPEI yang semakin luas sebagai Central Counter Party yang menyerap risiko 
kredit dari seluruh AK agar tidak berdampak lebih jauh terhadap pasar. Berdasarkan laporan Tahunan KPEI 2017,KPEI mencatatkan keberhasilan yang ditunjukkan dengan nihilnya kejadian kegagalan penyelesaian transaksi bursa oleh AK. Salah satu faktornya adalah kemampuan KPEI dalam mengelola risiko terkait dan makin matangnya sikap para pelaku pasar(KPEI,2017 : 20). Walaupun demikian, tetap diperlukan penguatan regulasi yang bersifat antisipatif bagi kedudukan KPEI.

Oleh karena itu, penelitian ini bertujuan untuk menganalisis dan mengkaji urgensi penjaminan dalam penyelesaian transaksi bursa untuk memberikan perlindungan hukum yang optimal bagi investor guna mendorong pengembangan pasar modal Indonesia.

\section{Metode Penelitian}

Penelitian ini menggunakan metode pendekatan yuridis normatif yang mengutamakan data sekunder berupa bahan hukum primer yaitu peraturan perundang-undangan, bahan hukum sekunder baik jurnal maupun hasil penelitian dan bahan hukum tersier. Spesifikasi penelitian bersifat deskriptif analitis, yaitu membuat pencandraan secara sistematis, faktual dan akurat mengenai fakta-fakta hukum. Oleh karena itu, penelitian ini sifatnya mengkaji dan menganalisis serta memaparkan hasil penelitian yang bersumber dari data sekunder yang dianalisis secara yuridis kualitatif.

\section{Hasil dan Pembahasan}

\section{Implikasi Hukum Perkembangan Regulasi Penjaminan Penyelesaian Transaksi Bursa}

Pertumbuhan pasar modal sebagai alternatif investasi tidak dapat dilepaskan dari kepercayaan investor terhadap pasar modal Indonesia. Banyak aspek yang menjadikan pasar modal Indonesia sebagai pilihan menarik, tidak hanya bagi investor asing namun juga bagi investor lokal. Berdasarkan data rekapitulasi nilai perdagangan saham berdasarkan tipe investor per Februari 2019, kontribusi investor asing sebesar $32,14 \%$, sedangkan investor domestik 67,86 \%. Dibandingkan dengan tahun-tahun 
sebelumnya, terdapat kecenderungan investasi asing yang menurun (OJK, 2019 : 7). Hal ini merupakan hal yang lazim terjadi dalam investasi di pasar modal dan tidak berarti pasar modal Indonesia bukan pilihan investasi yang menarik bagi investor asing. Portofolio investasi di Pasar Modal sangat dipengaruhi oleh kondisi global dan perubahan kebijakan di sektor keuangan lainya seperti perbankan. Berbeda dengan penanaman modal langsung yang sifatnya jangka panjang, portofolio investasi di pasar modal dengan mudah dapat ditarik kembali atau dipindahkan apabila tidak menguntungkan. Selain keuntungan, kepastian berinvestasi menjadi salah satu daya tarik bagi investor.

Oleh karena itu, Pasal 7 Ayat (1)

UU Pasar Modal mengamanatkan bahwa Bursa Efek didirikan dengan tujuan menyelenggarakan perdagangan Efek yang teratur, wajar, dan efisien. Berdasarkan penjelasan Pasal 7 Ayat (1) perdagangan efek secara teratur, wajar dan efisien adalah suatu perdagangan yang diselenggarakan berdasarkan suatu aturan yang jelas dan dilaksanakan secara konsisten. Dengan demikian, harga yang terjadi mencerminkan mekanisme pasar berdasarkan kekuatan permintaan dan penawaran. Perdagangan efek yang efisien tercermin dalam penyelesaian transaksi yang cepat dengan biaya yang relatif murah.

Berdasarkan tuntutan itu, pasar modal Indonesia menerapkan scripless trading system yang dapat memenuhi perdagangan yang teratur, wajar dan efisien. Dengan berlakunya sistem perdagangan ini fungsi Bursa, LKP dan LPP menjadi sangat penting. Untuk menciptakan kepastian dan perlindungan hukum, maka fungsi kliring dan penjaminan penyelesaian transaksi menjadi sangat relevan. Pertama, fungsi kliring akan memastikan apa yang menjadi hak dan kewajiban para pihak yang bertransaksi, sedangkan penjaminan penyelesaian transaksi oleh KPEI berfungsi untuk memastikan para pihak melakukan apa yang menjadi kewajibannya sehingga tidak ada gagal serah atau gagal bayar. Fungsi kliring dan penjaminan yang memberikan kepastian dalam bertransaksi ini 
menjadi salah satu pendorong dalam meningkatkan efisiensi pasar (Aime Tile Emmanuel, 2016 :34). Selanjutnya transaksi perdagangan di Bursa akan selesai setelah penyelesaian (settlement) yang dilakukan oleh KSEI dengan melakukan pemindahbukuan (bookentry settlement) dan menyimpan seluruh efek yang ditransaksikan dalam bentuk elektronik pada rekening di KSEI. Pihak yang dapat menjadi pemegang rekening di KSEI adalah Perusahaan Efek, Bank Kustodian serta pihak lain berdasarkan ketentuan peraturan perundang-undangan yang berlaku di Pasar Modal setelah memenuhi persyaratan dan terdaftar di KSEI. Khusus bagi pemegang rekening yang merupakan Perusahaan Efek yang juga anggota Kliring, KSEI akan membukakan Rekening Efek Penyelesaian yang digunakan khusus untuk penyelesaian Transaksi Bursa, yang terdiri dari : 1) Rekening Efek untuk penyerahan Efek dan atau dana kepada KPEI (Rekening Efek Serah); 2) rekening Efek untuk penerimaan Efek dan atau dana dari KPEI (Rekening Efek Terima); 3) rekening
Efek untuk menyimpan Efek dan atau dana yang dijaminkan oleh Anggota Kliring kepada KPEI (Rekening Efek Jaminan); dan 4) Rekening Efek untuk pelaksanaan kegiatan pinjam meminjam Efek antara Anggota Kliring (Rekening Efek Pinjam Meminjam). Per 28 November 2018, penyelesaian Transaksi Bursa dipercepat menjadi $\mathrm{T}+2$, yaitu 2 hari setelah hari transaksi (KSEI,2018). Perubahan siklus atau waktu penyelesaian transaksi bursa ini kemudian dituangkan dalam POJK No. 21/POJK.04/2018 Tentang Waktu Penyelesaian Transaksi Bursa.Hal ini sejalan dengan kemajuan teknologi informasi dan rekomendasi pengembangan pasar modal dunia. Penerapan $\mathrm{T}+$ 2ini dapat memberikan manfaat bagi industri diantaranya : 1) peningkatan efisiensi dan penurunan biaya penyelesaian secara jangka panjang; 2) penyelarasan waktu penyelesaian dengan Bursa Dunia yang telah menerapkan siklus penyelesaian $\mathrm{T}+2$; 3) likuiditas bagi pasar yang lebih tinggi, bahwa dengan waktu penyelesaian yang lebih cepat, efek 
yang telah dibeli oleh investor dapat dijual kembali dalam waktu yang lebih singkat sehingga pasar menjadi lebih likuid; 4) perputaran dan pemanfaatan dana yang lebih cepat. Sama halnya dengan efek, penjual akan menerima dana dan merealisasi gain 1 hari lebih cepat serta mempermudah investor untuk melakukan switching instrumen investasi lainnya hingga; dan 5) penurunan risiko counterparty dan pasar secara keseluruhan. Semakin lama waktu penyelesaian transaksi, semakin besar risiko yang akan dihadapi oleh ke dua belah pihak. Mempercepat siklus penyelesaian akan membantu memitigasi risiko pasar dengan mengurangi exposure antara pihak yang bertransaksi dan LKP itu sendiri (KSEI, 2016). Hal ini tentu akan memberikan keuntungan investasi bagi investor dan meningkatkan daya saing dan kredibilitas tingkat dunia. Selain keuntungan dari sisi ekonomi, perkembangan regulasi terkait penjaminan penyelesaian transaksi di bursa erat dengan aspek hukum. Penjaminan penyelesaian transaksi sebagaimana telah diuraikan berimplikasi terhadap 2 aspek hukum, yaitu :

\section{1) Percepatan peralihan kepemilikan efek sebagai objek transaksi.}

Perubahan aturan mengenai percepatan siklus penyelesaian transaksi dari $\mathrm{T}+3$ menjadi $\mathrm{T}+2$ berarti pula mempercepat peralihan efek sebagai objek transaksi menjadi $\mathrm{T}+2$. Percepatan peralihan kepemilikan efek ini tentu berdampak positif terhadap hak-hak pemegang efek atau penerima dana. Namun demikian, peralihan kepemilikan pada $\mathrm{T}+2$ ini tidak menghalangi pemilik efek untuk melakukan transaksi atau menjual kembali sebelum $\mathrm{T}+2$. Hal ini dapat dibenarkan berdasarkan kaidah hukum perjanjian. Apabila mengacu pada Pasal 1334 KUHPerdata, maka barang yang baru akan ada dikemudian hari dapat menjadi objek perjanjian. Ketentuan ini harus ditafsirkan bahwa barang yang akan dikemudian hari tersebut bukanlah sama sekali belum ada melainkan sudah ada alas haknya. Alas hak yang dimaksud disini adalah transaksi efek yang telah dilakukan 
dan disepakati oleh para pihak pada $\mathrm{T}+0$, sehingga telah menimbulkan kewajiban dan hak bagi para pihak. Lebih dari itu, Peraturan Perdagangan di Bursa Efek Indonesia (BEI) bahkan memperkenankan transaksi short selling untuk efek tertentu. Berdasarkan Pasal I.11 Keputusan Direksi PT Bursa Efek Indonesia No. Kep-00169/BEI/11-2018 Peraturan No. II-H Tentang Persyaratan dan Perdagangan Efek Dalam Transaksi Marjin dan Transaksi Short Selling, yang dimaksud dengan Transaksi Short Selling adalah "transaksi penjualan Efek dimana Efek dimaksud tidak dimiliki oleh penjual pada saat transaksi dilaksanakan sebagaimana dimaksud dalam Angka 1 huruf 1.l Peraturan Bapepam dan LK No. VD.6 Tentang Pembiayaan Transaksi Efek oleh Perusahaan Efek Bagi Nasabah dan Transaksi Short Selling oleh Perusahaan Efek, Lampiran Keputusan Ketua Bapepam-LK No. KEP-258/BL/2008 Tanggal 30 Juni 2008. Dengan demikian, ketentuan di Pasar Modal mengatur lain dari ketentuan Pasal 1334 KUHPerdata. Namun demikian, transaksi short selling ini diatur sangat berhati-hati, sehingga tetap memberikan kepastian dan perlindungan hukum bagi para pihak, khususnya pembeli. Kehati-hatian tersebut dapat dilihat dari antara lain : 1) efek yang ditransaksikan ditentukan oleh Bursa dan harus memenuhi syarat tertentu; 2) kewajiban menyediakan Efek Jaminan sesuai dengan daftar Efek Jaminan yang ditetapkan oleh Bursa; 3) Anggota Bursa yang memasukkan penawaran jual dalam rangka Transaksi Short Selling ke Sistem JATS (Jakarta Automated Trading System) wajib memberikan tanda Short pada penawaran jual dan penawaran yang dimasukkan ke JATS harus lebih tinggi dari harga yang terjadi terakhir (last done price).

Percepatan peralihan kepemilikan efek ini akan berdampak positif baik bagi pembeli maupun penjual. Penjual akan menerima dana lebih cepat sehingga likuiditas transaksi akan meningkat. Dari sisi pembeli, dengan peralihan yang lebih cepat, dapat menggunakan efek sebagai objek 
transaksi lebih cepat pula, misal untuk menjadikan efek sebagai objek jaminan guna memperoleh pembiayaan seperti kredit perbankan. Mengingat efek adalah surat berharga yang termasuk dalam jenis benda bergerak tidak berwujud, maka penjaminan saham yang diperdagangkan secara scripless (tanpa warkat) ini tetap menggunakan pranata gadai dan memenuhi syarat sah Gadai berdasarkan Pasal 1152 Ayat (1) dan Ayat (2) KUHPerdata (Lastuti Abubakar \& Tri Handayani, 2018 : 199).

\section{2) Perkembangan Pembaruan Utang (Novasi) Dalam Mekanisme Penjaminan oleh KPEI}

Apabila mengacu pada Pasal 1 Angka 1POJK No. 26/POJK/2014 Tentang Penjaminan Penyelesaian Transaksi, maka yang dimaksud dengan Penjaminan Penyelesaian Transaksi Bursa adalah "kewajiban LKP untuk seketika dan langsung mengambil alih tanggung jawab AK yang gagal memenuhi kewajibannya berkaitan dengan penyelesaian Transaksi Bursa. Demi hukum, seketika KPEI sebagai LKP akan memutus hubungan hukum yang muncul dari transaksi (perjanjian) jual beli efek antara Anggota Kliring Jual dan Anggota Kliring Beli yang bertransaksi. Dengan demikian, KPEI akan menggantikan kedudukan hukum baik Anggota Kliring Jual maupun Anggota Kliring Beli untuk melaksanakan kewajiban ke dua belah pihak. Apabila dicermati, maka hubungan antara Anggota Kliring Jual - KPEI - Anggota Kliring Beli mengandung unsur novasi (pembaruan utang) yang bersifat subyektif sebagaimana diatur dalam Pasal 1413 Ayat (2) KUHPerdata. Pasal 1413 KUHPerdata mengenal 3 macam novasi, yaitu novasi objektif apabila yang perbarui adalah objek perjanjiannya (Pasal 1413 Ayat 1); novasi subyektif yaitu apabila terdapat penggantian debitor ( Pasal 1413 Ayat 2) atau penggantian kreditor (Pasal 1413 Ayat 3). Sementara itu, KPEI menggantikan baik kreditor maupun debitor, sehingga dapat dikatakan bahwa novasi yang dilakukan adalah novasi subyektif baik aktif maupun pasif. Kedudukan KPEI yang menggantikan kedudukan para pihak 
ini diistilahkan sebagai mitra pengimbang atau counter party (Lastuti Abubakar, 2009 : 278). Dengan demikian, tampak bahwa pasar modal telah mengembangkan pranata hukum perdata, khususnya hukum perjanjian dan hukum kebendaan. Fungsi KPEI sebagai mitra pengimbang memastikan bahwa tidak akan terjadi gagal serah atau gagal bayar dalam penyelesaian transaksi bursa. Dengan demikian, setiap pihak yang bertransaksi di Bursa, sepanjang tidak melakukan kelalaian baik wanprestasi ataupun melakukan perbuatan melawan hukum, maka setiap investasi di pasar modal Indonesia dijamin penyelesaian transaksinya.

\section{Perlindungan Investor Melalui Penjaminan Penyelesaian Transaksi Bursa}

Perlindungan investor menjadi salah satu syarat bagi pasar modal Indonesia untuk menjadi pasar modal kelas dunia. Salah satu tujuan yang ingin dicapai yang terkandung dalam 38 prinsip dari peraturan sekuritas yang diterbitkan oleh IOSCO adalah perlindungan investor. Selanjutnya, ke 38 prinsip ini dikelompokkan ke dalam 10 kategori. Walaupun keseluruhan kategori tersebut erat kaitannya dengan tujuan yang ingin dicapai, namun kategori yang secara spesifik mengatur tentang penjaminan transaksi oleh LKP ini masuk ke dalam kategori ke 10 (J) yaitu Principles Relating to Clearing and Settlement yang mengharuskan seluruh regulasi terkait sistem penyelesaian efek, penyimpanan efek, dan fungsi mitra pengimbang dirancang untuk memastikan dan menjamian terciptanya pasar yang adil, efektif dan efisien dan mampu mengurangi risiko sistemik.

Berdasarkan POJK Penjaminan Penyelesaian Transaksi Bursa, KPEI bertanggung jawab untuk memenuhi kewajiban AK yang gagal. Jaminan penyelesaian Transaksi Bursa oleh KPEI dilakukan secara berjenjang dengan menggunakan beberapa sumber keuangan yang sifatnya prefunded yakni yang sudah siap digunakan dalam hal terjadi kegagalan penyelesaian transaksi Bursa. Berdasarkan POJK No. 26/POJK.04/2014 ada 3 sumber keuangan yaitu :1) Cadangan Jaminan yang berasal dari akumulasi 
dana yang berasal dari penyisihan laba bersih KPEI sebagai LKP dalam bentuk kas atau setara kas yang besarannya ditentukan oleh Rapat Umum Pemegang Saham (RUPS); 2) Fasilitas Kredit yaitu pinjaman yang diberikan oleh bank kepada KPEI dengan agunan tunai dengan jangka waktu fasilitas kredit yang diperoleh KPEI adalah 1 tahun dan kemudian dilakukan perpanjangan perjanjian; 3) Dana Jaminan yaitu dana yang berasal dari kontribusi awal AK dan kutipan sebesar $0,01 \%$ dari setiap transaksi bursa. Selanjutnya, apabila ke 3 sumber keuangan tersebut tidak mencukupi, KPEI akan menggunakan Jaringan Kredit yang sifatnya unprefunded, yaitu sumber keuangan yang belum tersedia dan akan dihitung nilainya sesuai kebutuhan. Mengacu pada mekanisme penjaminan penyelesaian Transaksi Bursa, maka KPEI mempunyai hak subrogasi kepada Anggota Kliring yang kewajibannya diambil alih. Hal ini merupakan konsekuensi logis bahwa tanggung jawab tetap melekat pada pihak yang wanprestasi, baik gagal bayar maupun gagal serah. Dengan mekanisme penjaminan penyelesaian transaksi di atas, maka regulasi telah memberikan perlindungan yang optimal terhadap potensi kegagalan penyelesaian transaksi. Dalam hal Anggota Kliring tidak dapat memenuhi sebagian atau seluruh kewajiban serah efek bersifat ekuitas kepada KPEI, maka Anggota Kliring wajib mengganti kewajiban serah efek tersebut menjadi kewajiban serah uang pengganti ( Alternate Cash Settlement) kepada KPEI, yang selanjutnya uang pengganti oleh KPEI diserahkan kepada pihak penerima efek. Alternatif Cash Settlement (ACS) ditentukan dengan menggunakan harga efek bersifat ekuitas pada $\mathrm{T}+0$ atau pada $\mathrm{T}+2$ baik di pasar reguler maupun pasar tunai, dipilih yang tertinggi. Artinya, kalaupun AK Beli tidak berhasil mendapatkan sahamnya akibat gagal serah, maka akan diganti dengan uang sebesar $125 \%$ dari harga tertinggi. Selanjutnya, terkait dengan sumber keuangan yang digunakan untuk penjaminan penyelesaian transaksi bursa sesuai dengan fungsi masing-masing sumber keuangan. 


\section{Penyediaan Agunan Sebagai Bentuk Pertanggungjawaban Anggota Kliring dalam Penyelesaian Transaksi Bursa.}

Dalam melakukan penjaminan penyelesaian transaksi, KPEI akan menggunakan sumber-sumber keuangan yang dikelola oleh KPEI untuk menggantikan kewajiban Anggota Kliring apabila terjadi gagal serah atau gagal bayar. Akibat hukumnya adalah terjadi penggantian kreditor (subrogasi) dari para pihak kepada KPEI. KPEI sebagai kreditor baru tentu mempunyai hak tagih kepada debitor (baik AK Jual dan AK Beli) berdasarkan ketentuan Undang-undang. Berdasarkan POJK Penjaminan Penyelesaian Transaksi, Anggota Kliring memiliki kewajiban untuk menyediakan Agunan.

Selanjutnya, Pasal 1 Angka 7 POJK Penjaminan Penyelesaian Transaksi “ agunan adalah dana, Efek, dan/atau instrumen keuanganlainnya milik AK sebagai jaminan yang dapat digunakan oleh LKP untuk menyelesaikan Transaksi Bursa dan/atau menyelesaikan kewajiban AK kepada LKP. Agunan ini disimpan dalam Rekening Jaminan, yaitu rekening Efek
Anggota Kliring pada lembaga Penyimpanan dan Penyelesaian (LPP) untuk menempatkan agunan berbentuk Efek dan/atau dana yang dapat digunakan oleh LKP untuk menyelesaikan Transaksi Bursa dan/atau untuk menyelesaikan kewajiban Anggota Kliring tersebut kepada LKP. Dengan demikian, Anggota Kliring Jual dan Anggota Kliring Beli tetap wajib bertanggung jawab atas kewajiban yang harus diselesaikan. Hal ini sejalan dengan fungsi penjaminan yang memastikan tidak terjadi gagal serah dan gagal bayar dalam transaksi di bursa.

\section{Gagasan Penggunaan Konsep Trust dalam Pengelolaan Dana Jaminan}

Isu hukum strategis lainnya dalam penjaminan penyelesaian Transaksi Bursa adalah kedudukan Dana Jaminan sebagai salah satu sumber keuangan KPEI dalam melakukan fungsi penjaminan. Berdasarkan POJK Penjaminan Penyelesaian Transaksi“ Dana Jaminan adalah kumpulan dana dan/atau Efek yang diadministrasikan dan dikelola oleh LKP yang digunakan untuk 
melakukan Penjaminan Penyelesaian Transaksi Bursa oleh LKP". Selanjutnya penggunaan Dana Jaminan untuk penyelesaian transaksi bursa wajib dibayarkan kembali oleh Anggota kliring yang gagal dalam memenuhi kewajibannya (mekanisme subrogasi). Beberapa hal terkait Dana Jaminan dapat diuraikan sebagai berikut :

1) Dana Jaminan berasal dari 2 sumber yaitu kontribusi awal Anggota Kliring baru sebesar Rp.5.000.000.000,- sebagaimana diatur dalam Peraturan KPEI No. II-3 Tentang Anggota Kliring; dan kontribusi Anggota Kliring pada nilai transaksi sebesar persentase tertentu dari nilai transaksi bursa yang telah diatur dalam POJK Penjaminan Penyelesaian transaksi dan Surat edaran OJK No. 23/SEOJK.03/2015 Tentang Kontribusi Dana Jaminan Berdasarkan Nilai Transaksi. Adapun nilai kontribusi Dana Jaminan untuk setiap produk adalah sebagai berikut : 1) untuk transaksi Efek Bersifat Ekuitas sebesar $0,01 \%$ dari nilai setiap transaksi; 2) untuk transaksi Kontrak berjangka Indeks Efek sebesar 0,0006\% ; 3) untuk Efek bersifat Utang dan Sukuk sebesar 0,00125\% ; dan 4) untuk Kontrak Opsi bersifat ekuitas sebesar 0,01 dari nilai kontrak opsi. Berdasarkan data yang dikeluarkan oleh KPEI, posisi Dana Jaminan per Maret 2019 sebesar Rp.4.589.476.116.874,64 atau kurang lebih 4,6 Triliun, sedangkan Cadangan Jaminan sebesar Rp. 148.569.268.411,00. Jumlah dana yang cukup besar untuk dikelola dan dimanfaatkan guna kepentingan penjaminan penyelesaian transaksi.

2) Hal menarik untuk dikaji dari aspek hukum adalah kedudukan Dana Jaminan yang bukan milik pihak tertentu dan tidak didistribusikan kepada siapa pun untuk keperluan apa pun kecuali untuk tujuan penjaminan penyelesaian transaksi. Hal ini berarti Dana Jaminan bukan milik KPEI dan bukan pula milik Anggota Kliring. KPEI hanya diberi kewenangan 
mengadministrasikan dan mengelola sedangkan manfaatnya dinikmati oleh industri pasar modal. Konsep pengelolaan Dana Jaminan yang tidak dimiliki oleh siapapun ini perlu diberi landasan hukum bagi kepemilikannya agar jelas kedudukannya. Dalam common law system terdapat pranata trust yang mengenal adanya dualownership, yaitu pemilik secara hukum (legal owner) dan pemilik manfaat (beneficial owner). Konsep trust ini diadopsi dan diadaptasi dalam POJK No. 25/POJK.03/2016 Tentang Perubahan Atas POJK No. 27/POJK.03/2015 Tentang Kegiatan Usaha Bank Berupa penitipan dengan Pengelolaan (Trust). Berdasarkan POJK Trust tersebut, Bank bertindak sebagai Trustee yang akan mengelola aset milik Settlor untuk kepentingan beneficiary (penerima manfaat). Secara teoritis, terdapat perbedaan yang substansial antara perjanjian penitpan dengan pengelolaan (trust) yang diatur dalam POJK dengan konsep trust yang berasal dari common law system. Dalam implementasinya di Indonesia, konsep trust dihadapkan pada aspek legal, mengingat konsep trust dalam sistem common law mengenal dual ownership, yang menempatkan trustee selaku pemilik hukum (legal owner) terhadap harta trust untuk kepentingan pihak ketiga (beneficiary) sebagai pemilik manfaat (beneficial owner). Konsep dual owner ship ini tidak dikenal dalam sistem hukum Perdata Indonesia. Hal ini menyebabkan implementasi konsep trust di Indonesia harus diadaptasikan dengan sistem hukum Indonesia ( Tri Handayani \& Lastuti Abubakar, 2014 : 2450). Eksistensi perjanjian Trust berdasarkan POJK Trust tersebut dimungkinkan berdasarkan sistem terbuka dan asas kebebasan berkontrak dalam hukum perjanjian (Pasal 1319 jo Pasal 1338 Ayat 1). Tampaknya, Pasar Modal pun dapat menggunakan konsep trust 
untuk memberikan dasar hukum bagi mekanisme pengelolaan Dana Jaminan oleh KPEI. Sebagai trustee, KPEI dapat secara optimal melakukan pengelolaan Dana Jaminan untuk kepentingan Pasar Modal sebagai penerima manfaat.

\section{Simpulan}

Berdasarkan analisis dan pembahasan yang telah diuraikan, maka dapat disimpulkan sebagai berikut :

1) Perlindungan hukum investor menjadi salah satu tujuan regulasi pasar modal untuk menarik investor pasar modal. Hal ini sejalan dengan karakter investasi dimana dana akan mengalir ke tempat yang mendatangkan keuntungan yang optimal dan jaminan kepastian hukum bahwa dana dan keuntungan tersebut dijamin akan diperoleh oleh investor. Selain itu, IOSCO (Internasional Organization of Securities Commissions) telah menerbitkan prinsip-prinsip dan tujuan pengaturan sekuritas, yang salah satu tujuannya adalah perlindungan investor. Untuk itu, fungsi penjaminan penyelesaian transaksi Bursa oleh KPEI selaku Lembaga Kliring dan Penjaminan menjadi urgen untuk memastikan agar tidak terjadi gagal serah dan gagal bayar. Dalam mekanisme transaksi Bursa, KPEI menjamian bahwa setiap pihak dipastikan memperoleh apa yang menjadi hak dan melaksanakan apa yang menjadi kewajibannya.

2) Untuk memastikan tidak terjadi gagal serah dan gagal bayar, KPEI mempunyai sumbersumber keuangan yang dapat digunakan untuk menjamin penyelesaian transaksi, yaitu Cadangan Jaminan, Fasilitas Kredit dan Dana Jaminan. Penggunaan sumber-sumber keuangan tadi tidak menghilangkan kewajiban Anggota Kliring yang gagal untuk membayar kembali kepada KPEI, dengan demikian terjadi subrogasi dalam mekanisme penjamin penyelesaian transaksi bursa. Selain itu, Anggota 
Kliring wajib memiliki Agunan sebagai jaminan untuk menyelesaikan transaksi. Selain digunakannya mekanisme subrogasi, kedudukan KPEI sebagai mitra pengimbang (counter party) yang akan menjamin penyelesaian transaksi dilakukan melalui novasi subyektif (baik aktif maupun pasif).

3) Dana Jaminan merupakan dana yang diadministrasikan dan dikelola oleh KPEI dalam rangka menjamin penyelesaian transaksi bursa. Dana Jaminan tersebut tidak dimiliki oleh siapa pun, dan tidak dapat digunakan oleh siapa pun untuk kepentingan apa pun kecuali untuk penjaminan penyelesaian transaksi bursa. Dari perspektif hukum, kedudukan Dana Jaminan ini memerlukan landasan hukum dalam pengelolaan dan pemanfaatannya. Oleh karena itu, perlu digagas dan dipertimbangkan penggunaan konsep trust sebagai dasar hukum bagi pengelolaan Dana Jaminan. Konsep ini telah dikembangkan sebagai salah satu pengembangan jasa perbankan yang mendudukkan Bank sebagai trustee yang dapat mengelola aset milik settlor untuk kepentingan penerima manfaat (beneficiary) yang dituangkan dalam POJK No. 25/POJK.03/2016 Tentang Perubahan Atas POJK No. 27/POJK.03/2015 Tentang Kegiatan Usaha Bank Berupa penitipan dengan Pengelolaan (Trust).

\section{Daftar Pustaka}

Abdul Qoyum.et.al,2017, Indonesian Capital Market Efficiency: Islamic vis-a-vis Conventional, ShirkahJournal of Economics and Business, Vol.2,No. 3, September-Desember https://www.researchgate.ne t/publication/322467664_In donesian_Capital_Market_E fficiency_Islamic_vis-avis_Conventional/download

Aime Tile Emmanuel,2016, The Central Securities Clearing System (CSCS) and Nigerian Capital Market Development : Empirical Evidence, ARC Journal of Business and Economic, Vol.1, Issue.1, 
http://www.arcnjournals.org limages/arc-jbe-10-1-3.pdf

Natalia Christanti \& Linda Ariany Mahastanti, 2011, Faktor Faktor Yang Dipertimbangkan Investor Dalam Melakukan Investasi, Jurnal Manajemen Teori dan Terapan, Tahun 4 No. 3 Dsember

Marchin Humanicki,Robert Kelm, Krzysztof Olzeweski,2013, Foreign Direct Investment and Foreugn Portfolio Investment in the Contemporary Globalized World : Should They be still Treated Separately, NBP Working Paper.167

Mohamad Heykal, 2013, Insider Trading dan Pelanggaran atas Prinsip Keterbukaan di Pasar Modal, Binus Business Review, Vol.4, No. 2

Intenational Organization of Securities Commission, 2018, Objectives and Principles of Securities Regulation, OIVC-

IOSCO,2017, https://www.iosco.org/librar y/pubdocs/pdf/IOSCOPD56 $\underline{1 . p d f}$

IDX-KPEI-KSEI, 2015 , Pengumuman Tanggal Implementasi Percepatan Siklus Penyelesaian Transaksi Bursa dari $T+3$ ke T+2, 2018, http://www.ksei.co.id/files/p engumuman-tanggal-

implementasi-siklus-

tplus2.pdf

KPEI, Tentang KPEI, PT kliring Penjaminan Efek Indonesia https://www.kpei.co.id/page /sekilas-kpei

KPEI, 2017, Laporan Tahunan KPEI 2017, PT Kliring Penjaminan Efek Indonesia

KSEI, 2016, KSEI Sebagai Lembaga Penyimpanan dan penyelesaian, PT Kustodian Sentral Efek Indonesia

Lastuti Abubakar, 2009, Transaksi Derivatif di IndonesiaTinjauan Hukum tentang Perdagangan Derivatif di Bursa Efek Indonesia, Bandung : Books Terrace \& Library

Lastuti Abubakar \& Tri Handayani,2018,

Perkembangan regulasi Pranata Jaminan Saham Tanpa Warkat (Scripless) Sebagai Objek Transaksi di Pasar Modal, Jurnal Justisia, Vol.2. No. 1 http://journal.umsurabaya.ac.id/index.php/Ju $\underline{\text { stitia/article/view/1715/1377 }}$

Laura Alfaro \&Jasmina Chaufin, 2017, "Chapter for Encyclopedia of International Economics and Global Trade, Direct Investment, Finance, and Economic Development, September 
Otoritas Jasa Keuangan, 2019, Kinerja OJK 2018- Memacu Pertumbuhan, 2018.

Otoritas Jasa Keuangan, Statistik Pasar Modal 2019, Jakarta , https://www.ojk.go.id/id/ka nal/pasar-modal/data-danstatistik/statistik-pasarmodal/Documents/5.\%20Sta tistik\%20Januari\%20Mgg\% 20ke-5\%202019.pdf

Tri Handayani \& Lastuti Abubakar, 2014, Implikasi Kegiayan Usaha Penitipan Dengan Trust) Dalam Aktivitas Perbankan Terhadap Pembaharuan Hukum Perdata Indonesia, Jurnal Litigasi , Vol. 15, No. 2 http://journal.unpas.ac.id/in dex.php/litigasi/article/view/ $\underline{68 / 362}$ 